\title{
Decreased Level of Fatigue in Aerobic Sports in the Use of Vitamin C
}

\author{
Junaidi and Tirto Apriyanto \\ FIO, State University of Jakarta \\ Jakarta, Indonesia \\ junaidi.sportmed@unj.ac.id
}

\begin{abstract}
This study aims to obtain information about reducing the level of fatigue in aerobic exercise in the use of vitamin $C$. This study uses an experimental method with correlational techniques, the sample used is the FIK-UNJ coaching study program students. Sampling using a purposive sampling technique. Hypothesis testing techniques are performed using simple correlation statistical analysis techniques followed by t-test at the significance level 0.05 The results of the initial test analysis and the final test of the aerobic group, obtained an average $=8.133$, standard deviation $=3.662$ and a mean standard error of SEMD $=0.945$. These results yield $t_{\text {-count }}=8.602$. Then with degrees of freedom $(\mathrm{df})=15-1$ at a significant level of $5 \%$, a critical value of $t_{\text {-table }}=1.761$ was obtained. With these results, it means $t$-count $<t$-table, the results of the study are significant.
\end{abstract}

Keywords: the decreased level of fatigue, aerobics, use of vitamin $C$

\section{INTRODUCTION}

Physical activity provides major changes to the body's metabolic rate [1]. Physical activity with different training intensities will require different energy expenditures (Sandi, 2019), for example when someone sprints or bikes with high intensity will require 40-50 times more energy expenditure compared to energy expenditure during rest periods. Whereas the marathon runners with submaximal intensity require energy expenditure of only 20-25 times compared to energy expenditure during rest.

When an athlete conducts training in large volumes or at very high intensity, fitness will increase but fatigue will also increase [2]. Fatigue occurs in everyone who does a physical activity with high intensity. Fatigue cannot be overcome only by rest, because fatigue can occur due to the energy metabolism system. In providing energy when doing sports that are less than perfect. Fatigue can be divided into two types, mental fatigue and physical fatigue [3]. Mental fatigue is usually caused by mental work while being physically tired due to muscle work.

Fatigue is just a symptom of the underlying condition, so to overcome it can depend on many things. Fatigue in highintensity sports and short duration is caused by excessive accumulation of lactic acid [4]. While fatigue in moderateintensity exercise and long duration due to lack of energy, lack of fluids and electrolytes and boredom. Moderate intensity exercise in a long duration is a picture of aerobic exercise. Aerobics is a type of exercise that stimulates the heart rate and breathing rate to increase rapidly during a sports session. Aerobics is known as cardio, a sport that requires oxygen to be sent to the working muscles [5]. The oxygen in question is derived and supplied from the heart through the blood. Therefore, both breathing and heart rate will usually increase rapidly during aerobic activity.

The American Heart Association recommends do this exercise for 30 minutes a day, 5 times a week with 10 minutes of brisk walking and repeated 3 times a day also meets the recommended rules. This exercise serves to maintain a healthy heart, lungs, and blood circulation system. With aerobic exercise, a person can increase oxygen uptake, increase the capacity of the blood to carry oxygen, reduce the pulse at rest and during activities. Aerobic exercise also increases the number of capillaries, decreases blood fat levels, and increases fat-burning enzymes [6].

Vitamin $C$ is a type of vitamin that is soluble in water and has an important role in various bodily functions. Vitamin $\mathrm{C}$ is a water-soluble vitamin, which means that the body does not store it. Therefore, we must get it through food, including oranges, broccoli, and tomatoes. This vitamin is also known by the chemical name of its main form, ascorbic acid. Vitamin $\mathrm{C}$ is a class of antioxidant vitamins that can ward off various extracellular free radicals. Some of its characteristics include being very easily oxidized by heat, light, and metals.

Vitamin $\mathrm{C}$ acts as an essential ingredient in the formation of collagen and elastin and for its growth [7]. Moreover, vitamin $\mathrm{C}$ functions as an alpha-ketoglutarate co-factor 2 required in the reaction of epsilon-N-trimethyl lysine hydroxylase and gamma butyrobetaine hydroxylase in the carnitine biosynthetic pathway. Carnitine serves as the mobilization of fat metabolism in the formation of energy. Vitamin C needs for growth and tissue repair in all parts of the body. Vitamin $\mathrm{C}$ will help the body make collagen, an important protein used to make skin, cartilage, tendons, ligaments, and blood vessels. Vitamin $\mathrm{C}$ also functions as a biosynthetic cofactor of carnitine, a substance that functions in the metabolism of body fat. Carnitine will accelerate fat mobilization for energy formation. Therefore vitamin $\mathrm{C}$ can prevent fatigue.

Fatigue leads to the inability to continue training at a certain intensity. In all sports, fatigue depends on many factors, such as fitness level and exercise intensity and environmental conditions (for example hot weather, humidity, and altitude). During strenuous exercises such as sprints, interval training, and high-intensity resistance/ weight training, the ability of muscle contractions depends on the formation of ATP to meet energy needs. In exercises with submaximal intensity, PCr is converted back into ATP, and the breakdown of glucose (glycolysis) to maintain the availability of ATP. If muscle contractions occur continuously, $\mathrm{PCr}$ will soon run out and will no longer be able 
to provide ATP. In skeletal muscle contraction, $\mathrm{PCr}$ is only able to provide energy for about 10 seconds, then runs out. To cover up the lack of ATP, the glycolytic process (glycolysis) will increase to produce additional ATP. But unfortunately, the increase in the process of glycolysis will be accompanied by a buildup of lactate and protons $(\mathrm{H}+)$, both of these products will cause fatigue. Proton accumulation causes a decrease in cellular $\mathrm{pH}$ (acidosis), which will interfere with muscle contraction through various mechanisms including inhibiting the action of the enzymes ATPase and PFK. Protons resulting from increased glycolytic processes will also interfere with the reaction of calcium ions with muscle myofilament proteins during muscle contraction, thus inhibiting the ability of muscle contractions. Unlike aerobic exercise, fatigue is not caused by lactic acid accumulation. In aerobic exercise, fatigue is caused by a lack of energy, fluids, and electrolytes. In moderate-intensity exercise and long duration, energy comes from fat metabolism. Based on the background above, the purpose of this study is to compare aerobic exercise with the use of vitamin $\mathrm{C}$ and an-aerobic exercise to reduce levels of fatigue.

\section{METHODS}

This study uses an experimental method with correlational techniques, the sample used is the FIK-UNJ coaching study program students. Sampling using a purposive sampling technique to collect data from the aerobic exercise group variable using Vitamin $\mathrm{C}$ which is taken is the data to reduce the level of aerobic exercise fatigue using vitamin $C$. Hypothesis testing techniques are performed using simple correlation statistical analysis techniques followed by t-test at the significance level 0.05. This research was conducted at Rawamangun Stadium, East Jakarta and was taken in July October 2019. Data Analysis Techniques used SPSS software ver. 18.0

\section{RESULTS AND DISCUSSION}

The results of the initial test analysis and the final test of the aerobic group, obtained an average $=8.133$, standard deviation $=3.662$ and a mean standard error of SEMD $=$ 0.945 . These results yield $t_{\text {count }}=8.602$. Then with degrees of freedom $(\mathrm{df})=15-1$ at a significant level of $5 \%$, a critical value of $\mathrm{t}_{\text {table }}=1.761$ was obtained. With these results, it means $\mathrm{t}_{\text {count }}$ $<\mathrm{t}_{\text {table }}$, the results of the study are significant, $\mathrm{H}_{0}$ is rejected and $\mathrm{H}_{1}$ is accepted, where the hypothesis is:

- $\mathrm{H}_{0}=$ No Reduction in Fatigue Level in Aerobic Sports. (rejected)

- $\mathrm{H}_{1}=$ There is a decrease in the level of fatigue in aerobic exercise (be accepted)

TABLE I. PAIRED SAMPLES TEST

\begin{tabular}{|c|c|c|c|c|c|}
\hline \multicolumn{2}{|c|}{ Paired Differences } & T & df & $\begin{array}{c}\text { Sig. (2- } \\
\text { tailed) }\end{array}$ \\
\hline Mean & $\begin{array}{c}\text { Std. } \\
\text { Deviation }\end{array}$ & $\begin{array}{c}\text { Std. Error } \\
\text { Mean }\end{array}$ & & & \\
\hline 8.133 & 3.662 & .945 & 8.602 & 14 & .000 \\
\hline
\end{tabular}

Energy is described as the capacity to do work. But this description is often conceptually difficult to understand how the work capacity can be measured. Finally, in the same way as mass can be measured in kilograms or pounds, work capacity can be measured in calories, abbreviated as Kcal, or in kilojoules ( $1 \mathrm{Kcal}$ is equivalent to $4,184 \mathrm{~kJ}$ ). Calories (Kcal) are defined as the amount of heat needed to raise the temperature of $1 \mathrm{Kg}(1,000 \mathrm{~mL} / 1 \mathrm{~L})$ of water by $1^{\circ} \mathrm{C}$ from $14.5^{\circ} \mathrm{C}$ to $15.5^{\circ} \mathrm{C}$. To measure calories a tool called calorimetry is used.

The body has two main pathway systems for supplying energy; aerobic pathway (oxidative or mitochondrial), which can only work when there is oxygen, and the anaerobic pathway, which works without the need for oxygen. The anaerobic pathway is further divided into two systems: phosphate as a ready-to-use energy system and anaerobic glycolysis system or lactate system. Each of these systems can produce ATP. The aerobic pathway is capable of producing large amounts of ATP, whereas the anaerobic pathway only produces a limited amount of ATP. The aerobic pathway produces ATP slowly, while the anaerobic pathway can produce ATP faster.

Aerobic respiration occurs within the mitochondria of cells, in general, the aerobic and anaerobic pathways can be distinguished by how intense or slow the training is. The intensity of this exercise will affect the path of energy production. When training with submaximal intensity and long duration, the system used is the aerobic system.

Based on the results of research that has been done, it can be found the results of research that show that in the group of subjects who consumed vitamin $\mathrm{C}$ were treated in the form of a static bicycle performance test for 45 minutes, so that in this test, their energy needs were met from burning fat. Vitamin $\mathrm{C}$ functions as an alpha-ketoglutarate co-factor 2 needed in the reaction of epsilon-N-trimethyllysine hydroxylase and gamma butyrobetaine hydroxylase in the carnitine biosynthetic pathway. Carnitine serves as the mobilization of fat metabolism in the formation of energy. Vitamin $\mathrm{C}$ can reduce damage to erythrocyte cells due to radicals [8]. Vitamin C can increase the mechanism of the antioxidant defense system in the body against free radicals

The more carnitine formed, the more fat is mobilized, so the more fat is burned. This fat is a source of energy during the test. So in this study, it was clear that vitamin $\mathrm{C}$ made a positive contribution to the test carried out with a duration of more than 30 minutes (in this study, the test was carried out for 45 minutes). The provision of vitamin $\mathrm{C}$ will make athletes who get maximum physical activity [9]. Therefore, in this group; there is a significant decrease in fatigue from the effects of consuming vitamin $\mathrm{C}$. This is in line with research findings [10] that vitamin $C$ can affect physical performance in athletes in terms of carnitine synthesis which plays a role in providing energy and improving immune function, especially endurance sports athletes who tend to be more susceptible to respiratory infections

\section{CONCLUSION}

Based on the results of the study, it can be concluded that the use of vitamin $\mathrm{C}$ in aerobic exercise shows a significant decrease in fatigue levels.

\section{REFERENCES}

[1] J. Galgani and E. Ravussin, "Energy metabolism, fuel selection, and body weight regulation," Int. J. Obes., vol. 32, no. 7, 2009.

[2] T. O. Bompa and C. Buzzichelli, "Periodization-: theory and methodology of training," Hum. Kinet., 2018.

[3] I. M. Y. Parwata, "Kelelahan dan Recovery Dalam Olahraga," J. Pendidik. Kesehat. Rekreasi, vol. 1, no. 1, 2015. 
[8] D. A. Saputro and S. Junaidi, "Pemberian vitamin c pada latihan fisik maksimal dan Perubahan Kadar Hemoglobin Dan Jumlah Eritrosit," J. Sport Sci. Fit., vol. 4, no. 3, 2015. no. $1,2013$.

[5] K. Ninzar, "Tingkat Daya Tahan Aerobik (Vo2 Max) Pada Anggota Tim Futsal Siba Semarang," e-Jurnal Mitra Pendidik., vol. 2, no. 8, pp. 738-749, 2018.

[6] C. M. Palar, D. Wongkar, and S. H. Ticoalu, "Manfaat latihan olahraga aerobik terhadap kebugaran fisik manusia," J. e-Biomedik, vol. 3, no. $1,2015$.

[7] D. Pakaya, "Peranan Vitamin C pada kulit," Med. Tadulako J. Ilm. Kedokt. Fak. Kedokt. dan Ilmu Kesehat., vol. 1, no. 2, pp. 45-54, 2014.

[9] R. N. Sinaga and F. A. Sinaga, "Pengaruh pemberian vitamin C terhadap kadar Malondialdehid dan Haemoglobin atlet pada aktifitas fisik maksimal," Gener. Kampus, vol. 8, no. 2, 2017.

[10] S. L. Mahfida, I. Kandarina, and A. Farmawati, "Efektivitas minuman kombinasi maltodekstrin dan vitamin $\mathrm{C}$ terhadap hitung jenis leukosit pada atlet sepak bola," J. Gizi Klin. Indones., vol. 11, no. 3, pp. 126$135,2015$. 